\title{
Mont-Saint-Michel and Chartres
}




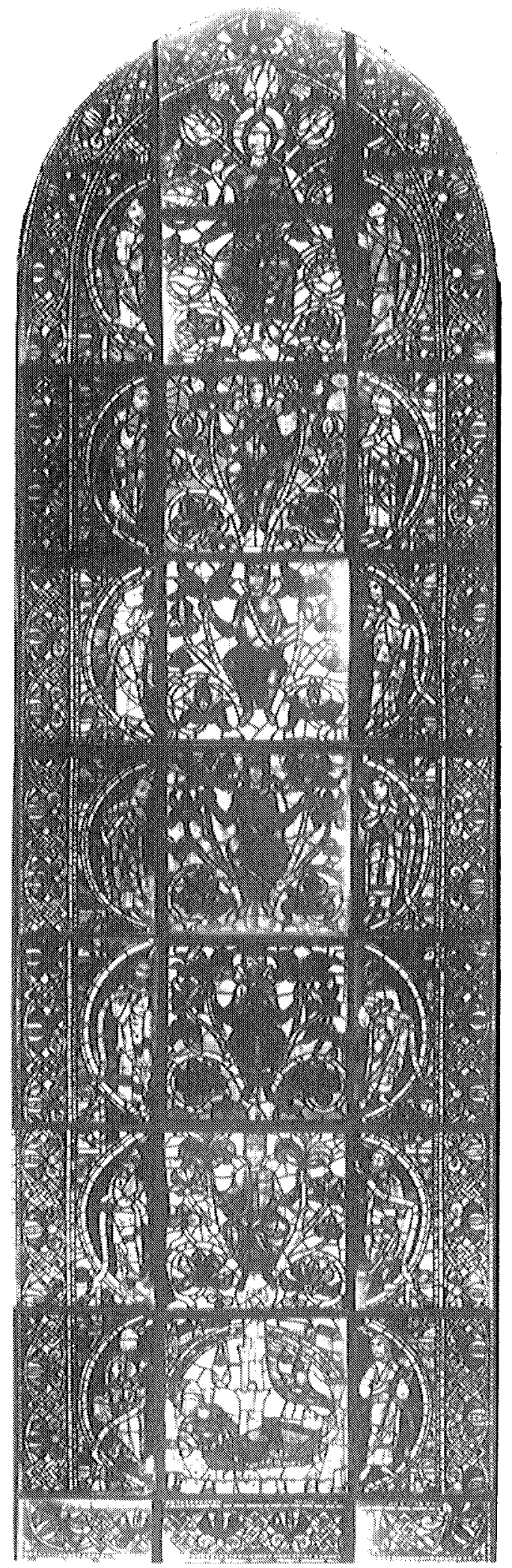




\section{Mont-Saint-Micbel and Chartres}

\section{BY \\ HENRY ADAMS}

WITH AN INTRODUCTION BY

RALPH ADAMS CRAM

Illustrated

Princeton University Press

Princeton, New Jersey 
Copyright $\left(C_{1905}\right.$ by Henry Adams

Copyright $(1933$ by Charles Francis Adams

Published by Princeton University Press, Princeton, New Jersey

In the United Kingdom: Princeton University Press, Chichester, West Sussex

$$
\begin{gathered}
\text { LCC 8I-47279 } \\
\text { ISBN o-69I-0397I-2 } \\
\text { ISBN o-69I-00335-I pbk. }
\end{gathered}
$$

Reprinted by arrangement with Houghton Mifflin Company

Authorized by the Massachusetts Historical Society

Princeton University Press books are printed on acid-free paper and meet the guidelines for permanence and durability of the Committee on Production Guidelines of the

Council on Library Resources

Printed in the United States of America by

Princeton Academic Press

First Princeton Paperback printing, 1981

Fifth Princeton Paperback printing, 1989

$$
\begin{array}{lllll}
7 & 9 & 10 & 8 & 6
\end{array}
$$

